\title{
THE OTTOMAN HAMMAM AL-WARD IN SAIDA, LEBANON
}

Received May 30th 2016 | Accepted July 26th 2016 | Available online December 20th 2016 | DOI http://dx. doi.org/10.18860/jia.v4i2.3485 |

Howayda al-Harithy

Department of Architecture and Design American University of Beirut

Beirut, Lebanon

hharithy@aub.edu.lb

\begin{abstract}
Hammam Al-Ward is an Ottoman monument in Saida. Siada (or Sidon) is a coastal city in Lebanon and a hidden treasure with numerous Mamluk and Ottoman monuments. These monuments are of various types, from mosques to hammams to palaces and khans. They remain unstudied and at times undocumented. This is an architectural monograph of Hammam Al-Ward placed within the urban history of the city and the social practices of its inhabitants. Through documentation and comparative analysis, the paper argues that the hammam was built during the early eighteenth century but carries within it an old tradition of building that dates back to the Mamluk period and an old socio-spatial practice that dates back to Roman times. The article investigates and presents the urban condition that unfolds through the hammam patronage, style and location, the architectural interpretation of the hammam type of the Mediterranean Arab World and the socio-spatial practices of bathing and leisure that continue till modern times.
\end{abstract}

KEYWORDS:

Islamic; Architecture; Hammam; Mamluk; Ottoman; Saida

\section{INTRODUCTION}

Hammams, or public baths, have historically functioned as one of the key elements of public life in Medieval Islamic cities. The medieval walled city of Saida was home to hammams dating from the Mamluk and Ottoman periods, some of whichwere fully functional untilquite recently.Aspaceboth sacred and mundane, the hammam served hygienic and religious purposes where ritual purity (tahara) could be obtained. An extension of social life, it also fostered a sense of community by serving as a secular site of leisure and respite.

Hammam al-Ward, built in the heart of the city in the early eighteenth century, was the last one to have been built. This monograph is both an historical and architectural record of the surviving hammam presented in the context of the city and its dwellers. The methods are therefore dependent on reconstructing the urban context of the time, surveying and documenting the building, and on comparative analysis that locates Hammam Al-Ward within the historic evolution of the hammam building type in the Mediterranean medieval period.

\section{HISTORICAL CONTEXT}

The commission and construction of hammams and other monuments in eighteenth century Saida was very much connected to the patronage of prominent local families who took advantage of the resources made available to them by the ruling elite. Construction of the built environment became both a symbol and a means to political power and social status.

Early seventeenth century Saida was marked by the ruleof a local amir: Fakhreddin al-Ma'niyyal-Thani (1572-1635). Despite its status as a subunit (sanjaq) annexed to the province of Damascus, Saida nevertheless becamean important center for the powerful amir'spolitical activities and patronage, which was reflected in the built environment. Saida witnessed an unprecedented momentum of urban development: constructions of khans (such as khan alFranj), palaces (Saray Fakhreddin), mosques (alQtayshiyyamosque), madrasas and hammams (hammam al-Mir) were built in response to the booming economic, demographic and social needs of the time (Figure 1). By the end of Fakhreddin's rule, descendants of the Ma'n family (mainly the Shehabis, amirs of Shouf) struggled to maintain their authority and establish good relations with Saida's rulers [1].

Saidawas declared an independent province (wilaya) in 1660, a strategic and an administrative measure brought about by Ottoman authorities with the aim to exert greater control over their provinces and to keep an eye on potentially rebellious locals [1]. A series of short-term rulers were appointed to govern Saidaand a consequence of this quick turnover of 
rulers was that long-term development plans for the city becamebarely viable.

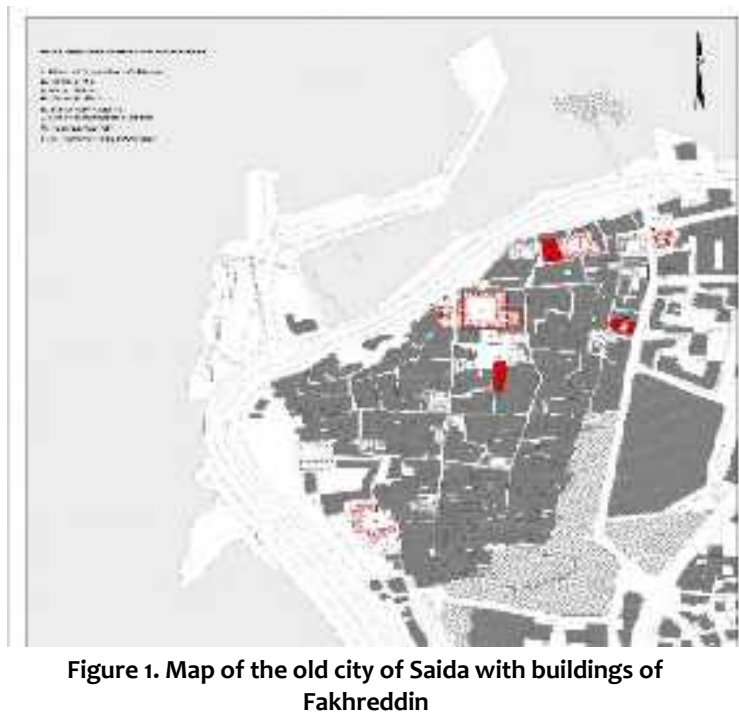

Members of the al-'Azm familyruled Saida at different time intervals, mainly Suleyman Pasha al'Azm (from 1728 to 1730) and As'ad Pasha al-'Azm (1730-1734). Al-'Azms are a local Damascene ruling elite, mainly appointed to Damascus, Tripoli and Saida [2]. The rise of al-'Azm familyin the eighteenth century was due to a host of factors such as long and recurrent tenure of governmental positions, knowledge of provincial affairs as well as Ottoman service, extensive local connections, and nepotism in Damascus but in the neighboring provinces as well [2]. In Damascus, the power of the al-'Azmsis particularly visible in their contributions to the built environment [2]. These include public and private constructions such as interventions in suq al-Buzuriyyin of Isma'il Pasha, public baths such as hammam al-Khayyatin in 17261727 , and madrasas such as the madrasa of Isma'il Pasha in 1730. During the reign of Isma'il Pasha, the first 'Azm ruler of Damascus from 1724 to 1730, a large number of plot acquisitions and construction projects made an important impact on the urban fabric of Damascus of the eighteenth century, mainly in the vicinity of the citadel and to the south of the Umayyad mosque [2], setting the path for a long family tradition of patronage of both private and public projects.

Suleyman Pasha al-'Azm was the first ruler of this family to govern Saida from 1728 until 1730, right after a two-year rule of Tripoli. Suleyman's reign in Tripoli was marked by violent struggle against the French and missionary influences and also against rebellious officials and local powers. However, in Saida, Suleyman was more moderate, especially towards French economic activities, accommodating the intricate economic and social composition of the city and its balance of powers [2]. The second 'Azm leader of Saida was Asa'ad Pasha, ruling from 1730 until 1734 [1]. He was successful in establishing good relations with the French and protecting the pilgrimage routes from Bedouin attacks, which had a positive impact on Saida's commerce. Asa'ad Pasha was renowned for the number of buildings he commissioned in Damascus and Hama during his fourteen uninterrupted years of rule there. In pursuit of personal wealth and power, the'Azm walis often failed in their administrative duties and in confronting their enemies, illustrating the failure of Ottoman administration in its provinces [3].

Within this political context, local notables, a'yansurged in power and made many contributions to the city, the most powerful was the Hammoud family. Rising social and economic needs related to the demographic jump from 6000-7000 inhabitants in the middle of the seventeenth century to 9000-11000 in habitants in the eighteenth century instigated a building boom [4]. Additionally, flourishing commercial activities in Saida also fueled the important social, urban and economic roles played by this prominent family. The momentum of local power took shape through waves of constructions, at different periods. It continued the urban transformation of Saida and the economic rise that mainly started with Ma'n family, throughout the patronage of Fakhreddin.Social and cultural exchanges within the ruling elite circles, at the service of Ottoman authorities, are well expressed in the similarity of architectural and stylistic trends of buildings commissioned at the time.

\section{PATRONAGE}

The Hammoud family left a strong imprint on local affairs as well as on the urban fabric of Saida between the eighteenth century and the first half of the nineteenth century: orchards, residences, and several shops are counted among the Hammouds endowments of 1818-1860 [5]. The family's growing financial strength is reflected through the commission of various private and public constructions that still stand today in the walled city such as the enlargement of al-Bahr mosque, hammam al-Jadid, khan alHummus/al-Qishla, Dar Debbane (1721-1722), and Dar 'Ali Hammoud (1730), also known today as the Madrasa of 'Aisha, that recalls the spatial configuration and decorations of Damascene residences. "The Hammouds have built everything in Saida, except a hospital" is a popular localsaying in Saida that underscores the power of this family [6].

Originally from Maghrib, the Hammouds are believed to have settled in Saida between the sixteenth and the seventeenth century, amassing a remarkable fortune over the years. They were known to be tax collectors for the Ottoman authorities since 1665. Moreover, the fiscal reform of 1695 guaranteed them a long-term right to collect taxes (malikane) that was then passed down to a succession of family descendants [7].

As an indication of their powerful political role in Saida, the Hammouds supported walis of Saida and were in direct contact with them. Mustafa and his son 'Ali Agha are two of the most influential figures of the Hammoud family, as argued by Weber (2010) in his study of French consular reports of Saida in the seventeenth and eighteenth century.

Accumulation of property and wealth, contribution to local real estate affairs, the role of trustee of awqaf and financial affairs of Saida and 
sometimes Damascus (through the connections with walis) were mostly transmitted from Mustafa to his son 'Ali Agha, in continuation of the family's powerful presence in the city. 'Ali Agha Hammoud played a key role in the political life of Saida, occasionally taking over governor duties and fulfilling important mediating responsibilities between the wali and the French consulate [7]. His contribution to the built environment is still present today. Two waves of construction characterized the rich patronage of 'Ali Agha Hammoud in Saida, known for his extravagant taste. Around $1721 / 1722$ he was appointed to the position of tax collector after his father's death and built Dar Debbane (1721-1722), (Figure 2) and khan alHummus (1721-1722), (Figure 3). The second period is a decade later, towards the end of his life when his second residence, Dar 'Ali Hammoud (1730), (Figure 4), and hammam al-Ward (1730-1731), (Figure 5).
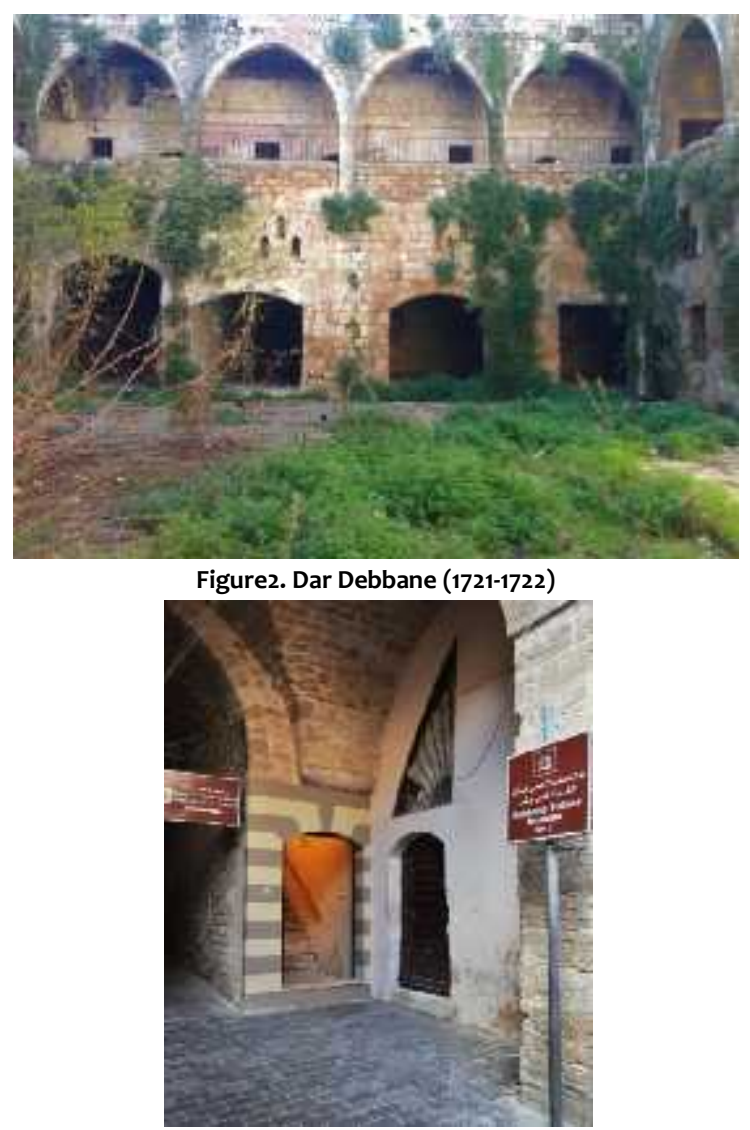

Figure 3. Khan al-Hummus/ al-Qishla (1721-1722) renovated between 2006 and 2010 by the Debbane Foundation

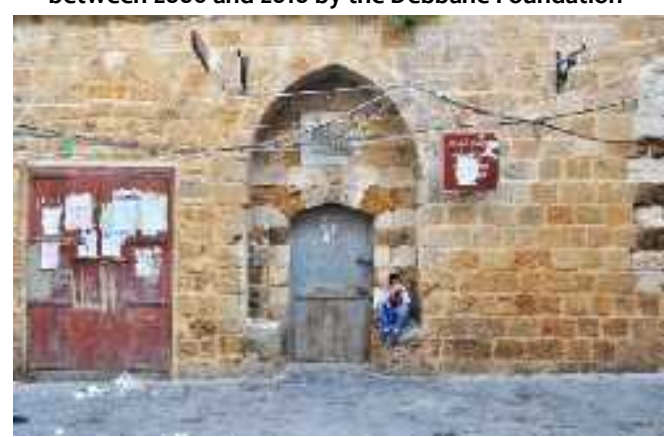

Figure 4. Dar Ali Hammoud (1730) recently restored by the Harir Foundation and the Association of Saida for Heritage and Environment

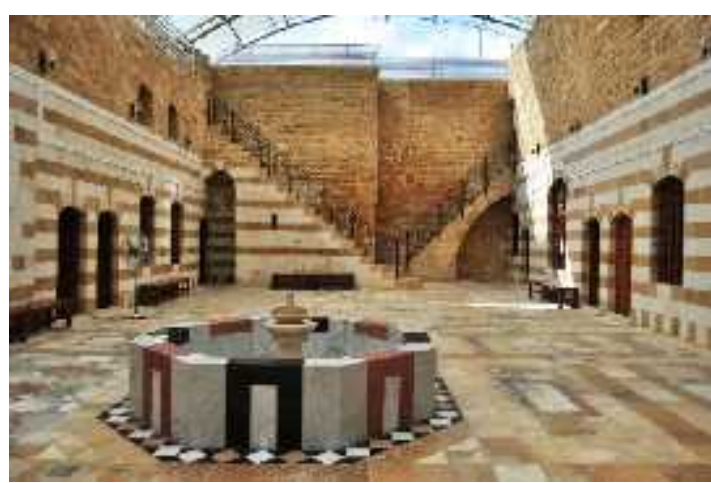

Figure 5. Hammam al-Ward (1730-1731)

\section{LOCATION}

Hammam al-Ward occupies a corner site in the south western quarter of the old city (Figure 6). Its location is shared by two religious landmarks: to its south, al-'Omari Great Mosque, erected on the remains of a crusaders' fortress in 1291 and to its east, the adjacent Zawiyat al-Zaatari/Qadiriyyawhich dates back to the Ottoman period (no exact date is known) and opens onto Sahat Dahr-al-Mir (Figure7). It gets its name from the crossing of two streets along the northsouth and east-west axis where it is located: the crossing or msalabiyya of hammam al-Ward.During the Ottoman period, the entire neighborhood was named after hammamal-Ward: 'harathammam al-Ward' as mentioned in the court registers of 1858 [5]. The foundation inscription at the entrance of al-Ward references a public water fountain, sabil, created along side the hammam for the use of passers-by, a common social and religious practice that promoted welfare [8].

و سبيل الماء في هذا الطريق

"Building the hammam [...] and the water fountain on this road"

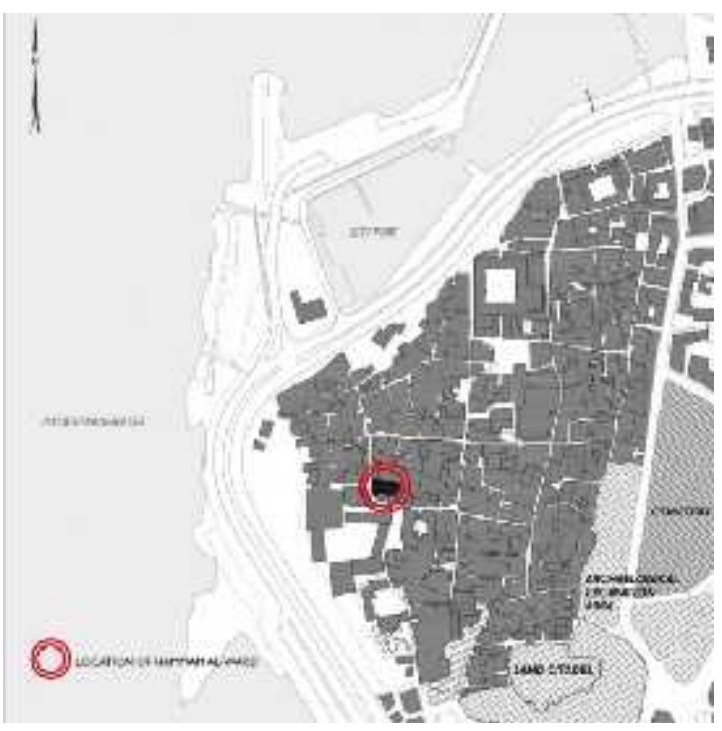

Figure 6. Map of Saida with Location of Hammam Al-Ward 


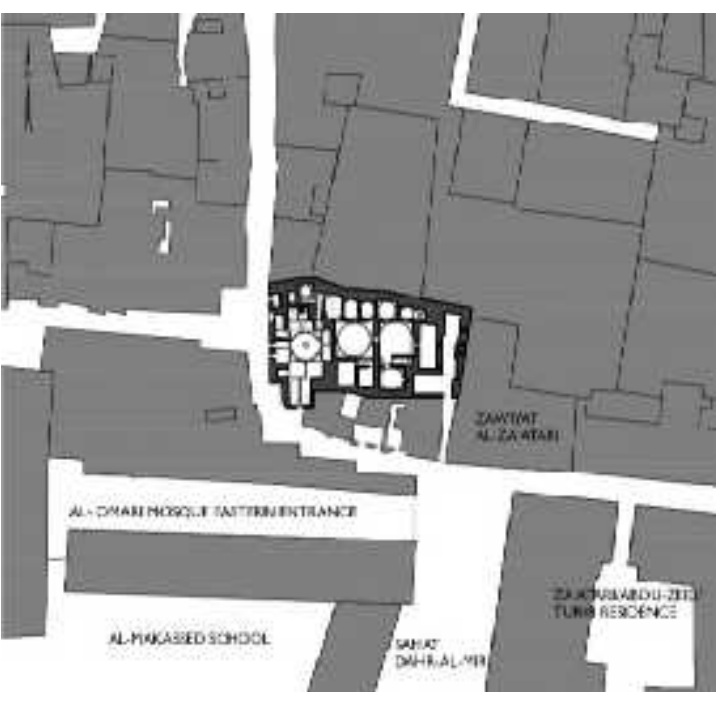

Figure 7. Hammam al-Ward Plan and Location

\section{DATE OF CONSTRUCTION}

Hammam al-Ward was the last hammam to be built and dates back to eighteenth century Ottoman Saida. It was built in $1143 \mathrm{AH} / 1730 \mathrm{CE}$ according to the foundation inscription above the hammam's entrance. Worth mentioning that there is a small discrepancy between the date inscribed on the foundation panel. The text date reads $1143 \mathrm{AH} / 1730 \mathrm{CE}$ (thalathat wa arba'oun wa maya wa alf) whereas the numbers date reads $1133 \mathrm{AH} / 1719 \mathrm{CE}$ (Figure 8 ). The carved rhyming inscription alsomentions the patrons of this hammam: " " (Hammoud family).

$$
\begin{aligned}
& \text {..... } \\
& \text { و سبيل الماء في هذا الطريق }
\end{aligned}
$$

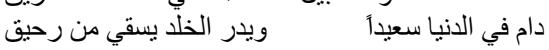

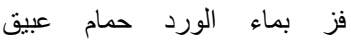

$$
\begin{aligned}
& \text { " ثلاثة وأربعون وماية وألف } 1133
\end{aligned}
$$

Saida had counted four earlier hammams: al-Suq (no date of construction is found), al-Shaykh (sixteenth century), al-Mir commissioned by Fakhreddin in the seventeenth century (demolished during the 1980s) and al-Jadid commissioned by the Hammouds as well in the first decade of the eighteenth century. During his trip to Saida, at the onset of the eighteenth century, al-Nabulsi, a Damascene traveler and writer, mentions three hammams: Al-Suq (the smallest), alShaykh and al-Mir in Saida and describes the abundance of water and marble flooring of Hammam al-Mir in detail [9].

Therefore, the two new hammams al-Jadid and al-Ward were built by the same family within the same timeframe (beginning of the eighteenth century), indicating a phase of booming urban development initiated by the patronage of the Hammouds.

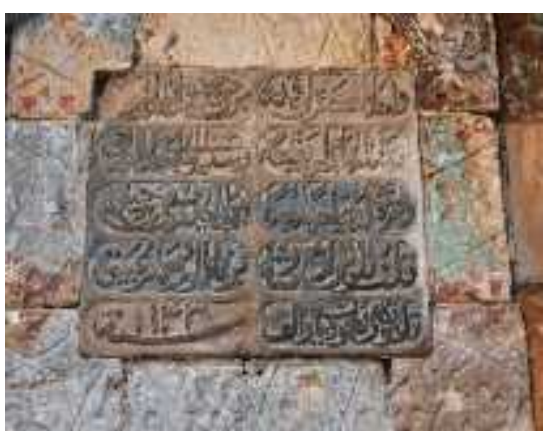

Figure 8. Foundation Inscription above the entrance of Hammam al-Ward

\section{ARCHITECTURE OF THE HAMMAM TYPOLOGY}

The key sequential arrangement in a typical hammam is one that transitions spatially and thermally from the most public to the most private and from the coldest to the warmest temperature zones. This hammam belongs to the linear hammam typology and not the central because its major spaces are organized in linear fashion along a single axis. This linear configuration is also found in other earlier hammams of Saida, such as hammam al-Mir (seventeenth century) which represents a more rational layout due to its location on the edge of the city (Figure 9) and hammam al-Jadid, built around 1714 (Figure 10).

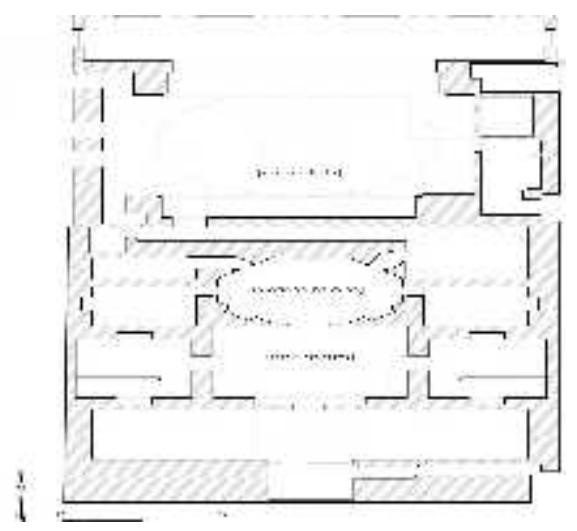

Figure 9. Hammam al-Mir Plan, Saida

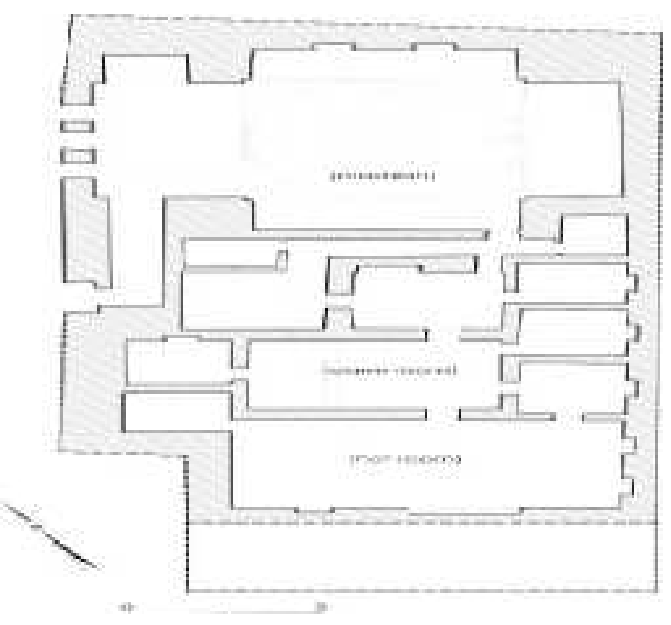

Figure 10. Hammam al-Jadid Plan, Saida 
Three major spaces and three transitional spaces follow the common sequence and thermal adjustment from cold to warm to hot rooms, in hammam al-Ward. These are articulated differently. The first transition is an outside/inside one: a bent corridor connects the portalon thestreet to the first major space inside the hammam, the cold room (mashlah), through a second door. This cruciform hall is an intermediate space between the cold outside and the warmer and more humidinside of the bathing spaces. The second transition happens between the mashlah and the sequence of bathing spaces. It is articulated through a long narrow corridor bending ontoan intermediate room. This feature, in addition to thick walls, is essential in preventing heat loss. Finally, a direct passage interconnects the warm room (wastani juwwani) and the hot room (juwwani harara). The similarity of activities in these two spaces as well as thenecessary heat exchange dictates such a direct and linear transition (Figure 11). Form, scale and proportions of spaces illustrate the spatial organization of hammam al-Ward, a regional interpretation of hammam typology in Medieval Eastern Mediterranean. Hammam al-Ward's mashlah translates a cruciform configuration. It spans 15 meters approximately along the north-south axis, versus 8 meters along the east-west axis. The two main bathing spaces and their connected bathing rooms (maqsura) form a consistent cluster at the east side of the whole building. They are both square-shaped and of similar dimensions ( $5 \times 5$ meters). Their maqsuratare linearly juxtaposed on the northern and southern sides of the hammam with direct connections to the two large bathing spaces. The warm and hot rooms in hammam al-Wardoutsize the cold room in dimensions and scale. The latter is reduced to a $2.5 \times 4$ meters transitional space, breaking away from the hammam typology of theMamluk period such as hammam 'Izziddinein Tripoli (Figure 12) [10].

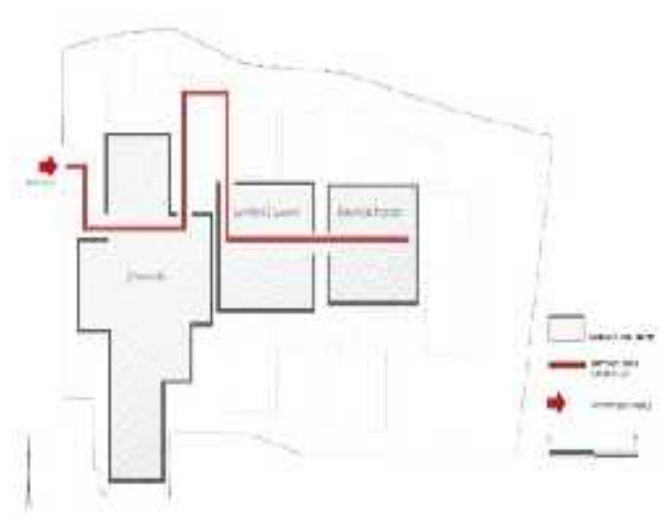

Figure 11. Typology diagram

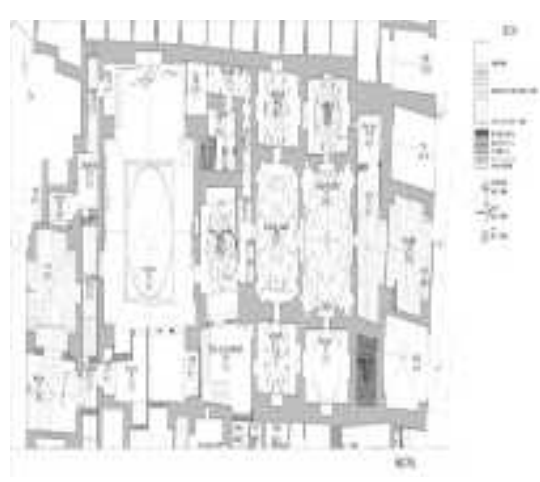

Figure 12. Hammam ‘'zzidin Plan, Tripoli

The spatial organization and the hierarchy of spaces indicate that the hammam belongs to the eighteenth century trend of hammams in the region that can be traced back to fifteenth century with the tendency for elaborate the bathing rooms, particularly the hot room. Ecochard and LeCoeur's analysis of the typological evolution of hammams in Damascus from the twelfth to the eighteenth century illustrates that hammams retain the three sequential spaces (cold, warm and hot) but give increasing importance to the hot room as a main bathing space with its own maqsurat [11]. Though it does not emphasize the hot room over the warm room, hammam al-Ward shows a variation of the regional trend as outlined by Ecochard and LeCoeur whereby the hot room has its own maqsurat.

\section{PLAN}

From the street, hammam al-Ward is entered through a one-meter wide bent corridor connecting the portal to a secondary inner door opening to alarge square hall: al-mashlah. The bent corridor has a typical dual function. It offers privacy and controls draft. The mashlahconsists of a low reception area of about $5 \times 5$ meterswith an octagonal water basin at its center and a dome crowning it. Four vaulted and elevated iwans, of about $80 \mathrm{~cm}$ in height, accessed through a couple of wooden steps, define the main square space. Mashlah is where the social exchange happens: hammam guests are welcomed, they remove their clothes, get ready for bathing but also rest and socialize after the bath. Spared the excessive heat and humidity, mashlah allows for a different architectural treatment than the rest of the hammam's spaces: large spans, a high dome, as well as windows and clerestory openings (Figure 13).

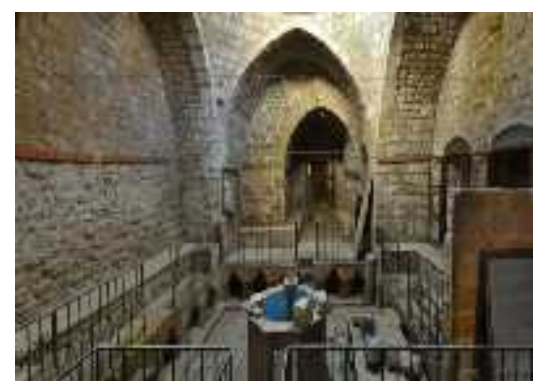

Figure 13. Hammam al-Ward, view of themashlah 
These characteristics are further translated through the building materials, all mashlah walls are built with limestone that could be left exposed. The fact that the dome is plastered and painted suggests that the mashlah's walls may have been painted as well when first constructed. The variations of sizes of these mastabatallow the mashlah more room for activities. It is important to note that the southern mastabaextends deeper to the south to form an iwan offering an additional 6 meter seating area to the hammam's users. The same observation applies to the northern mastaba too, creating a larger seating iwan but also accommodating for the staircase taking up to the hammam's rooftop. This arrangement of spaces gives al-Ward's mashlah its cruciform configuration. Small niches are carved of stone at the base of each one of iwan as spaces to store the users' clogs. Carvings of these niches are different from each other showing a diversity of mastered stone craftsmanship. Hammams in the region show variations in the form, scale and proportions of their mashalih. A similar cross-shaped configuration with different proportions and dimensions is spread among Saida's hammam al-Jadid and hammam al-Shaykh (Figure 14). Hammam al-Nuri in Tripoli features deep iwan spaces on each of its 4 sides (Figure 15) whereas hammam al-Jadid in Tripoli features iwan spaces of equal depth (Figure 16). As the hammam's largest space, special attention is always given to al-mashlah's proportions and ornamentation as an indicator of the hammam's grandeur but also a reflection of the patrons' wealth and social status. A 5 meter high domecrowns the four vaulted mastabat of the main hall. Sitting on a polygonal base of 12 sides, the dome is decorated with plastered patterns all around. The base is punctured with small clerestory windows lighting the mashlah. A skylight at the dome's tip provides extra lighting at the very center of this space. Additionally, two large windows on the western iwan serve additional lighting and ventilation purposes.

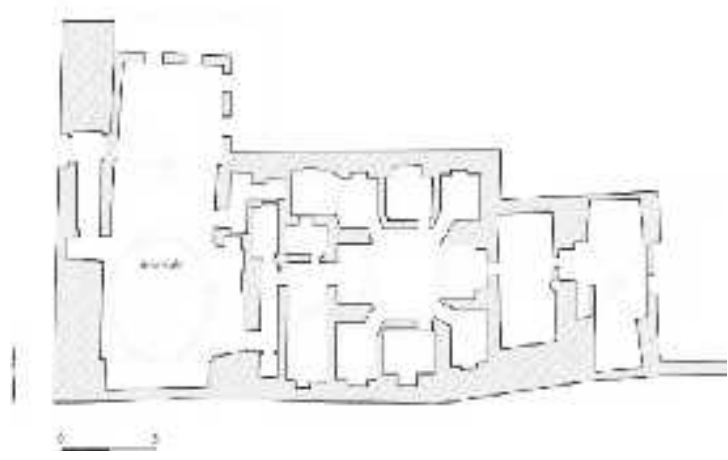

Figure 14. Hammam al-Shaykh in Saida, Plan

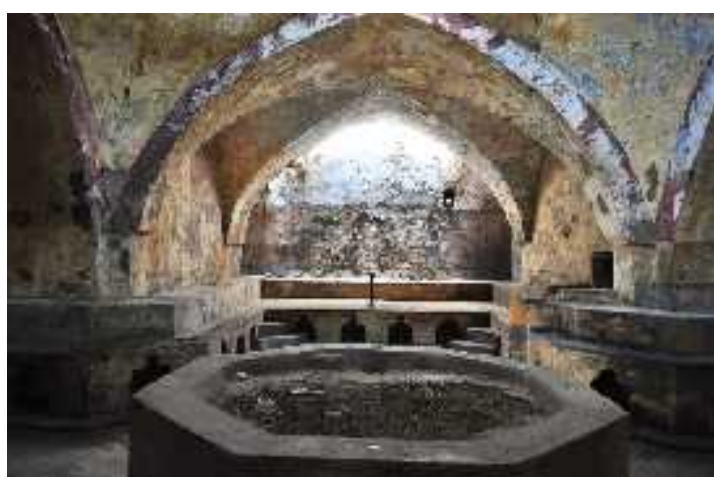

Figure 15. Hammam al-Nuriin Tripoli, view of the iwan space

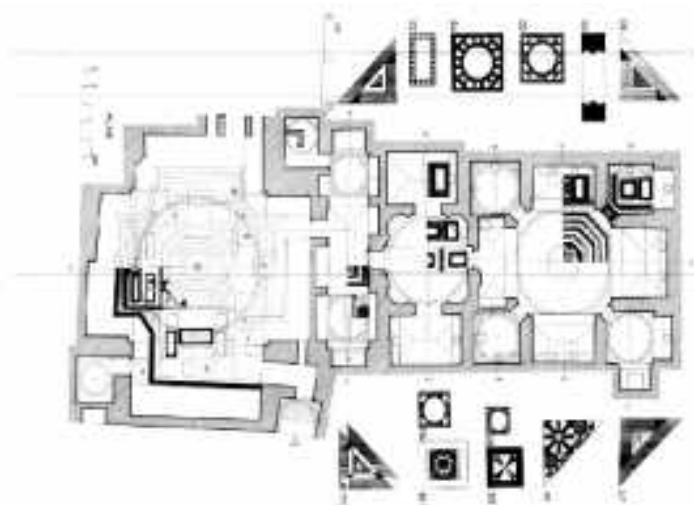

Figure 16. Hammam al-Jadid in Tripoli, Plan

From this main hall, a narrow vaulted door leads to the inner bathing spaces, where the preservation of heat and waterproofing is the main construction concern and embodied by the arrangement of rooms, construction of thick walls, the absence of any opening to the outside and the treatment of tiles and drainage system (Figure 17) [11]. A long narrow 80 centimeters corridor and an intermediateroom measuring $2.5 \times 4$ meters form the transition: wastani barrani. It is warmer than al-mashlah but isthe coldest in the sequence of bathing spaces. This space forms a programmatic extension to al-mashlah since it is also functions as a changing room by users who cannot tolerate the difference in temperature, especially in winter. Therefore, it is also called mashlah al-shita' (winter changing room). The corridor is also connected to two small service rooms and toilets. 


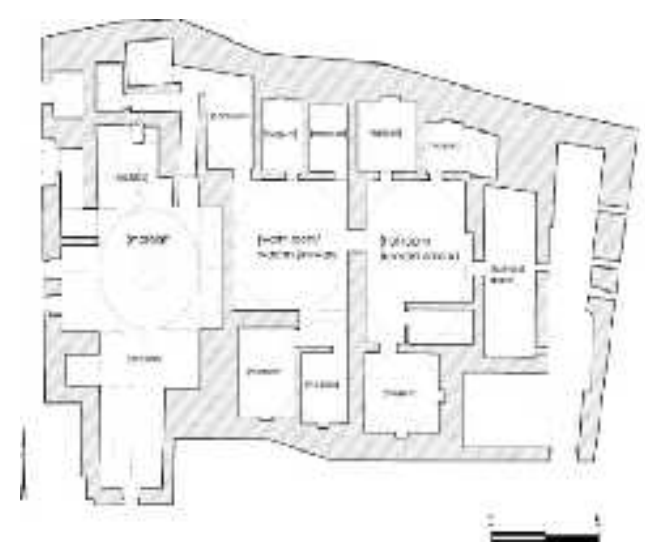

Figure 17. Hammam al-Ward Plan

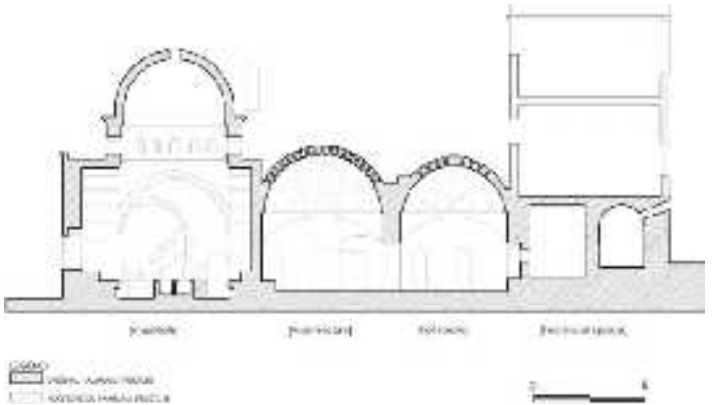

Figure 18. Hammam al-Ward section

A succession of two large bathing spaces which are thewastani juwwani and the juwwani harara define the actual hammam space (Figure 18). The names of the bathing spaces are closely aligned to their featured temperatures. Wastani juwwaniis a washing space that has generally a lower temperature, while wastani hararais the hottest part of al-Ward. Its eastern wall separates it from the hot water tank and is perforated with holes to provide steam of the boiling water tank. A seating space is provided on this wall, where users sit to sweat before getting a massage treatment in a private maqsurasof the hot room. Bathing areas and their connected spaces are all covered with domed ceilings. Patterned perforations covered with colored glass are the only source of light in the hammam.

Wastani juwwani (Figure 19) and juwwani harara (Figure 20) are compartmented and connected to smaller, more private washrooms maqsurat, of similar dimensions with nichedgurns (washbasins) providing hot water to the hammam users (Figure 21). Maqsurat are generally small in size ( $2 \times 2$ meters approximately) with two or three washbasins in each. They are more private spaces of hammams where showering and massaging happen. With their visibly rusted plumbing pipes-a result of earlier restoration works-scratched marble floor and plastered walls covered with growing moisture patches, the washing rooms are the most deteriorated spaces of hammam al-Ward.

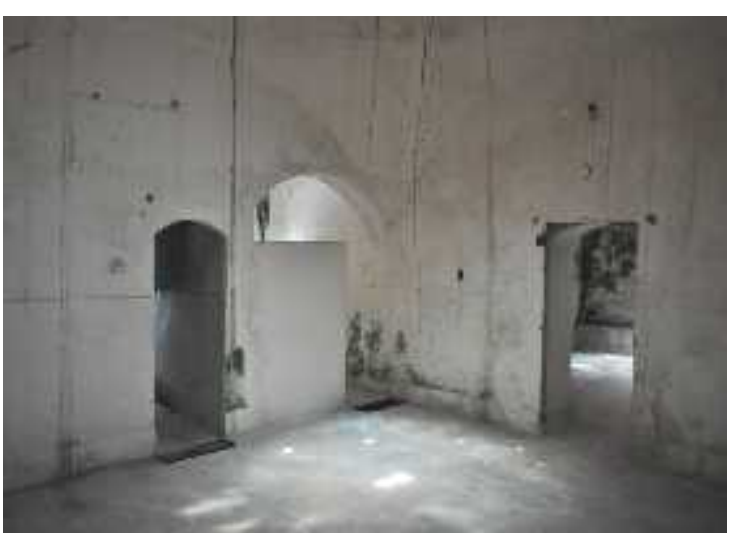

Figure 19. Hammam Al-Ward, Interior view of the Warm room

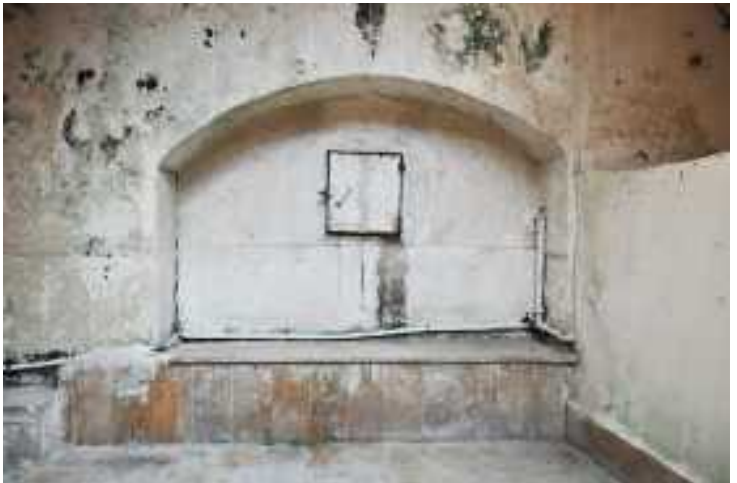

Figure 20. Hammam Al-Ward, Interior view of the Hot room

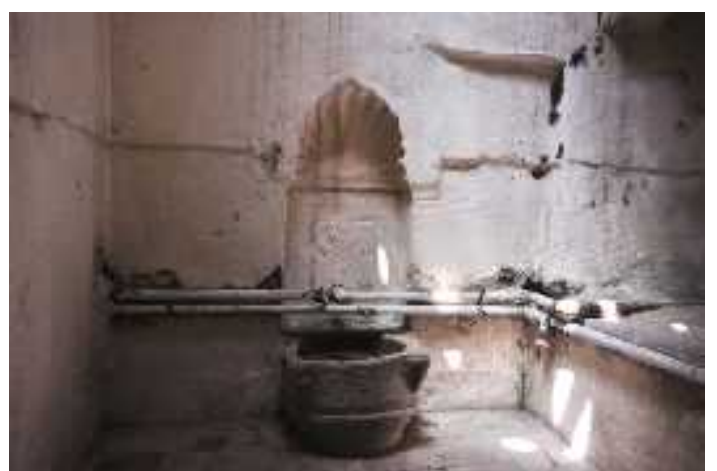

Figure 21. Hammam Al-Ward, Interior view of a maqsura

\section{TECHNICAL SPACES}

Hammams in Saida operated throughout the day with the mornings designated for men and the afternoonsreserved for women and children [8]. Therefore, before and during working hours, hammam al-Ward needed to be adequately heated and provisioned with hot water for its guests. The heating system is a duct system. While the steam is released into the hot room through an opening on the eastern wall, smoke is channeled through the duct that runs underneath the floor of the bathing spaces before reaching the chimney located behind the mashlah.

The hammam's technical spaces are located at the far eastern side of the block, accessed separately through a door adjacent to Zawiyat al-Zaatari. The furnace/Bayt al-Nar lies at the end of the axis and 
against the eastern wall of the hot room. It follows the conventional arrangement of a water tank with a fire place underneath it. It is important to note that the water tank is lower in height than the rest of the hammam in order to preserve the heat. Water, arriving through the city's distribution system from al-Awali River or al-Hara source is heated by burning wood or combustibles in thefurnace (qamim) and heating the water tank [8]. Hot water is distributed to all of the hammam's gurns through low pipes either embedded in the walls or exposed.

The hammam forms a self-regulatory climatic entity through the presence of an active component (the furnace producing heating energy) and another passive component for cooling. The cold room (mashlah) is the hammam's passive area where the internal thermal-dynamic devices are used to insure thermal comfort both in summer and in winter. These normally include air stratification and movements, fountains, and high ventilation.The dome-fountain combination is used for regulating the temperature in this area of the hammam, as other areas are more dependent of active systems. In summer, the windows are open and allow for the hot air to escape as the fountain performsevaporative cooling. This does not occur in winter since the windows are shut and the water is drained from the fountain there by retaining the warmth inside.

\section{CONSTRUCTION MATERIALS}

Almost all hammams in the region make use of local craftsmanship and share the same building techniques and local materials. In Saida, as in many of the coastal cities, the main construction material is limestone, hajar ramli. It is visible on the hammam elevation as well as on the interior of the mashlah space where no heat or humidity are possible. Other local materials are used for different parts of the hammam taking into account two main concerns: waterproofing and humidity. The humid domes of bathing areasare covered with a mixture of earth and layers of mortars which is burnt limestone mixed with water, leaving a white interior with minimal ornamentation, except for some en-relief floral patterns in some corners. The floor of the hammam is covered with white marble with different patterns in each section.

\section{ARCHITECTURAL ELEMENTS}

Due to its deteriorating state as well as the repeated restoration works undergone on the hammam al-Ward, it is difficult to ascertain whether or not the original decorations are still intact. Looking at the main hall or mashlah, the most striking decorative element would be the visible en-relief patterns executed on the dome (Figure 22). Although it is difficult to date their execution, they still add a touch of finely-crafted beauty to the grandeur of the entire space. Niches carved under the elevated changing spaces are quite unique in their execution: each one has its own delicately carved pattern (Figure 23).
Tiling is another important feature of this space; different patterns decorate the floor of the mashlah (Figure 24). In the hot and humid spaces, decorations are more sparse. Although, the two main washing rooms are covered with white limestone, a main decorative feature is present: pendentives supporting the domes are decorated with en-relief patterns of flowers that were covered over the years with layers and layers of finishing (Figure 25).

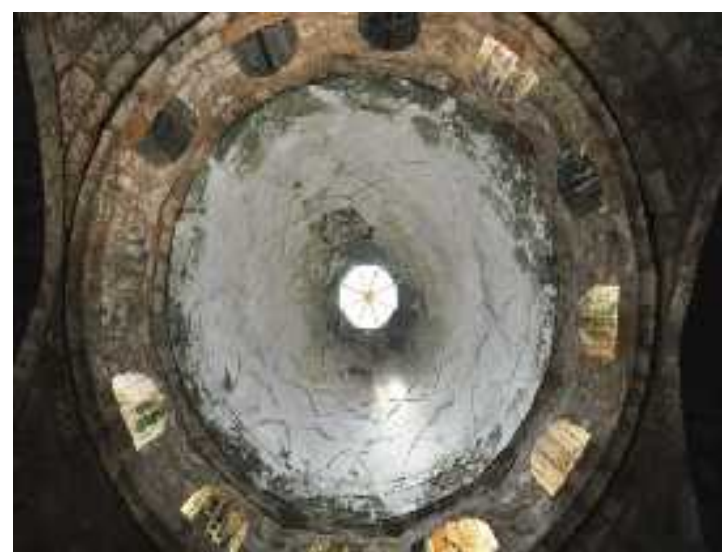

Figure 22. View of the dome over the Mashlahroom

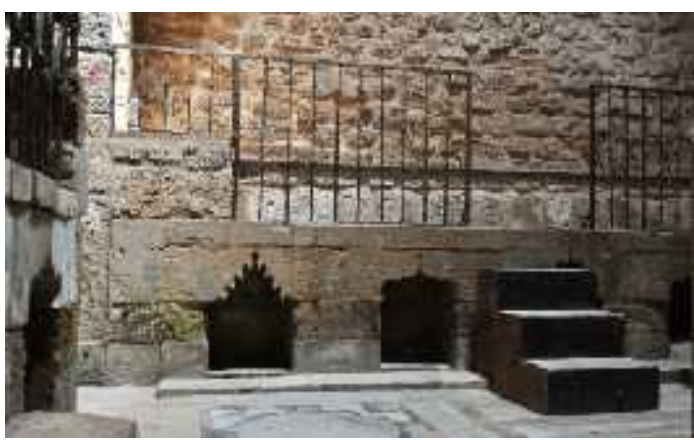

Figure 23. Niches within mastabatof mashlah

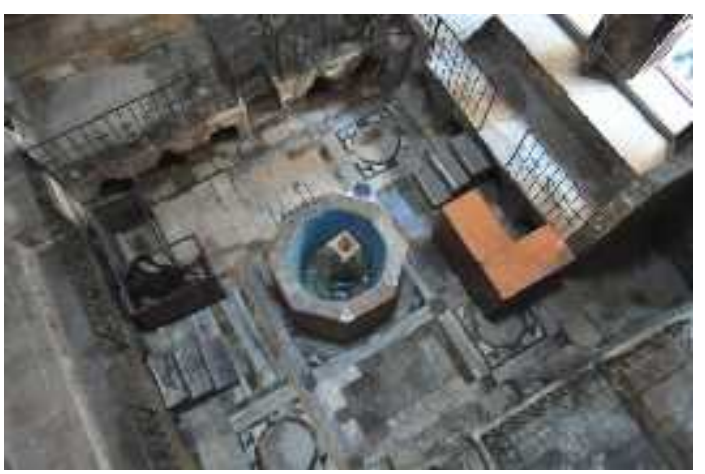

Figure 24. View from above showing the Mashlah tiling 


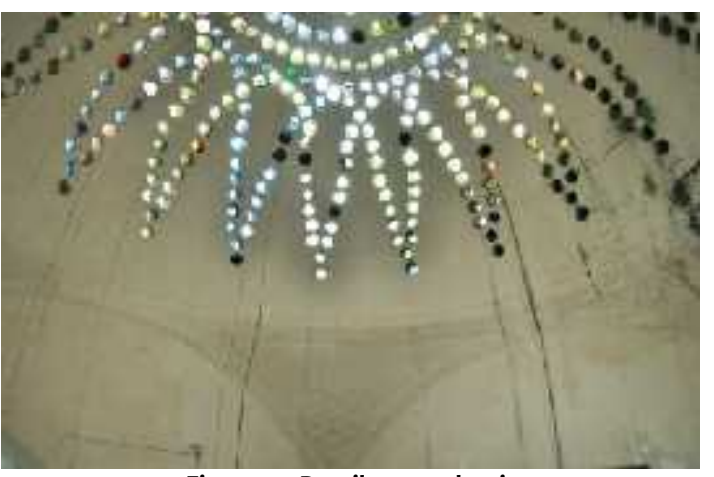

Figure 25. Detail on pendentive

The two large washing spaces and their attached maqsurat are lit by the colored glass cylinders inserted in their dome, their layout also form floral patterns. Ward, which means 'flowers' in Arabic, have a strong presence in this hammam, giving it a special character (Figure 26 and 27).

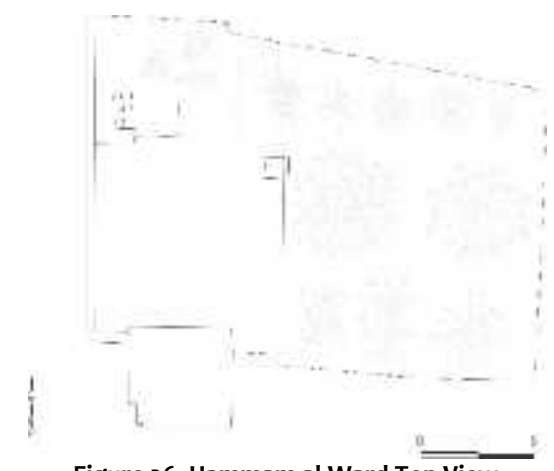

Figure 26. Hammam al-Ward Top View

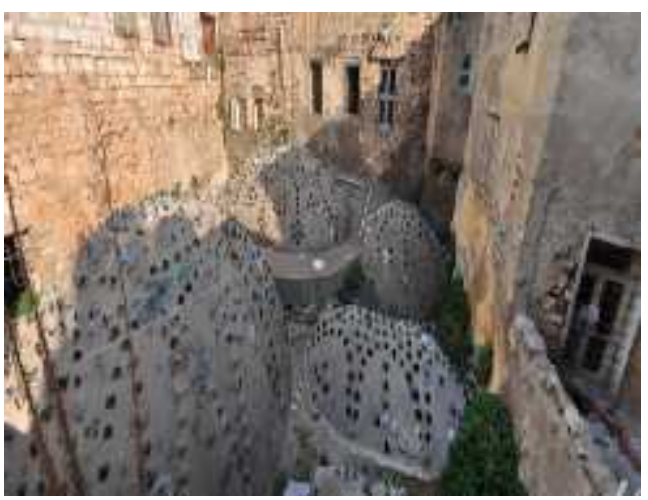

Figure 27. Hammam al-Ward Rooftop View

\section{MAIN ELEVATION}

The need for heat preservation and a preference for privacy dictatethe simple, hermetically sealed elevations that are mostly concealed in the urban fabric except for the side of the entrance. The organic morphology of the old city and its tightly-knit fabric further advanced this purpose sincehammam al-Ward blends in with its surroundings.

The main elevation [Figure 28 and 29] gives a hint of the division of spaces inside it through the elements that compose it. The entrance is recessed and defined by a pointed arch (Figure 30). The entrance door is also inserted in a rounded arch above which is installed with a foundation inscription with the date of construction inscribed in Arabic. This recessed entrance panel of a similar height (around 3.5 meters) is found in two other hammams of Saida: hammam alShaykh (Figure 31) and hammam al-Jadid (Figure 32). Different decorative carvings adorn each portal imbuing each hammam with its own specificity: three carved floral patterns characterize al-Ward's portal (Figure 33) whereas for the earlier-constructedalShaykh, it is a stone pattern framing the entrance's arch. Hammam al-Jadid's original entrance remains unique, displaying rows of muqarnas (Figure 34). A higher volume with the main dome on top of it, defining the mashlah, is juxtaposed next to the entrance with two windows protected by grilled iron.
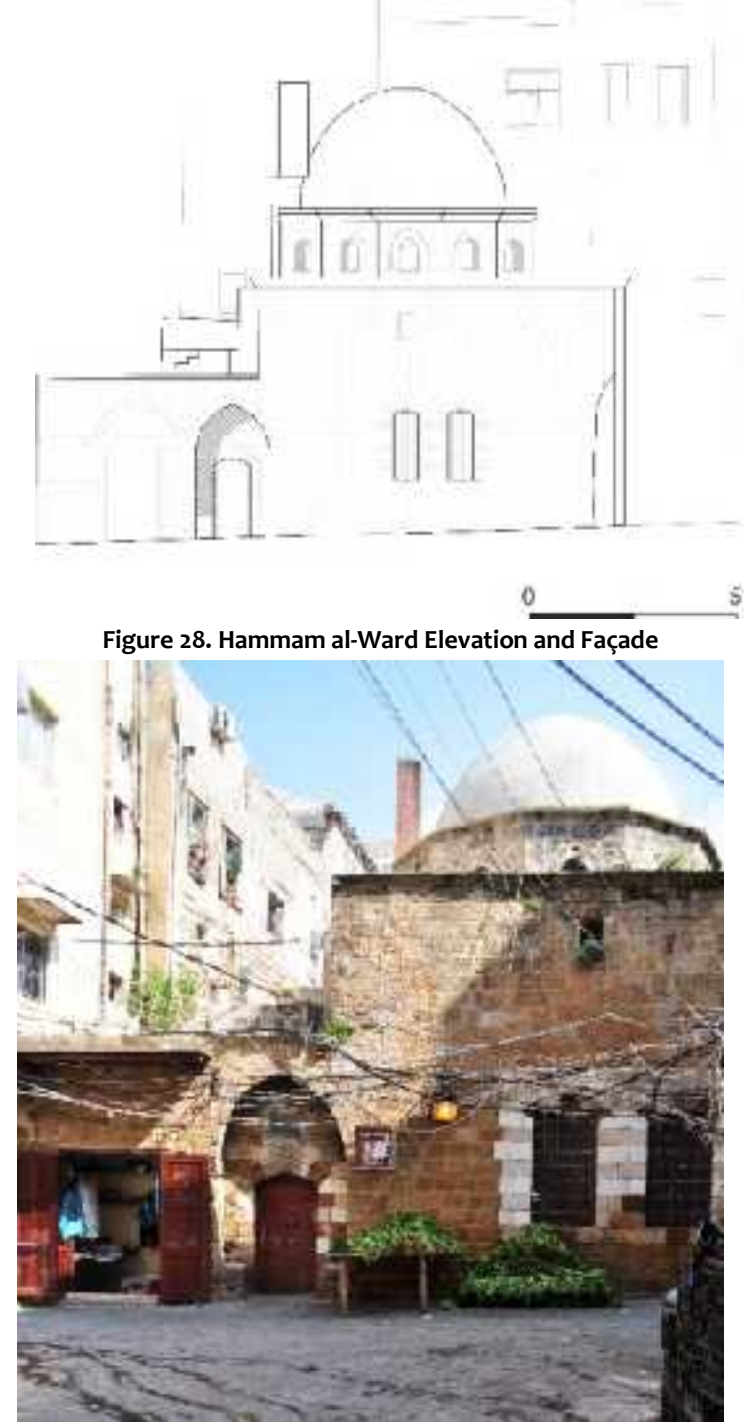

Figure 29. Hammam al-Ward Elevation and Façade

The three openings on this façade are framed by two colors of limestone: a white one and a yellow one, characteristic of Ottoman stylistic detailing or ablaq (Figure 35). This style is repeated in hammam al-Jadid and could be an indication of the adopted style of this period in Saida (Figure 36). Also noteworthy is the presence of another single window on the southern wall of mashlah. This opening could pass unnoticed since it gives way to a vaulted passage on the alleyway. 
The adjacent building shares the remaining southern part of hammam al-Ward and partly hovers above the street.

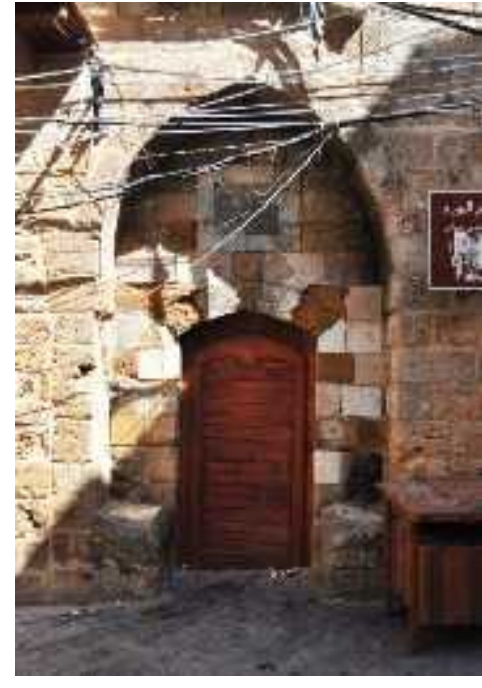

Figure30.Hammam Al-Ward portal

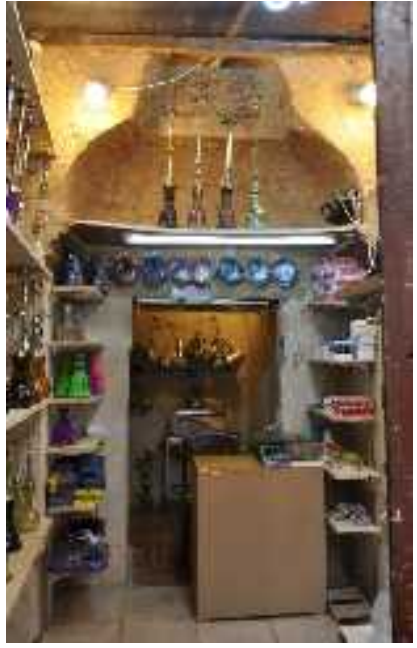

Figure31.Hammam Al-Jadid portal

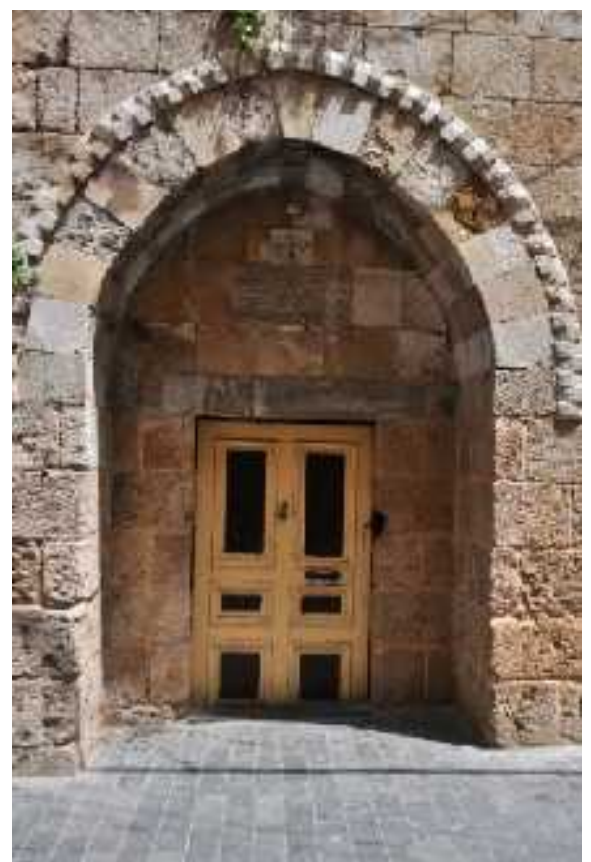

Figure 32.Hammam Al-Shaykh portal

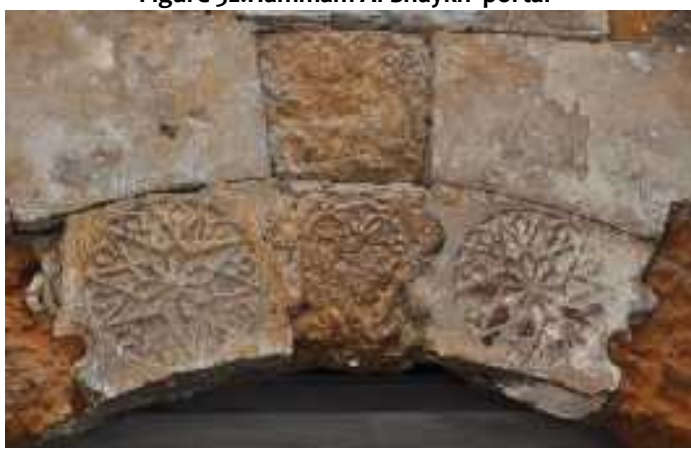

Figure 33. Hammam Al-Ward entrance decorative detail

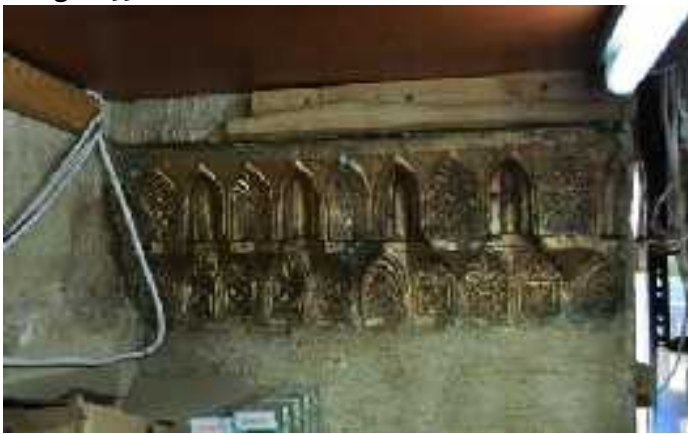

Figure 34. Hammam Al-Jadid entrance decorations

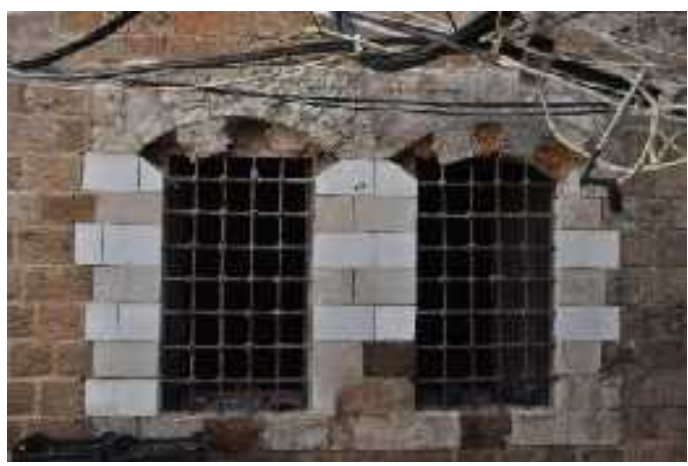

Figure 35. Hammam Al-Ward windows 


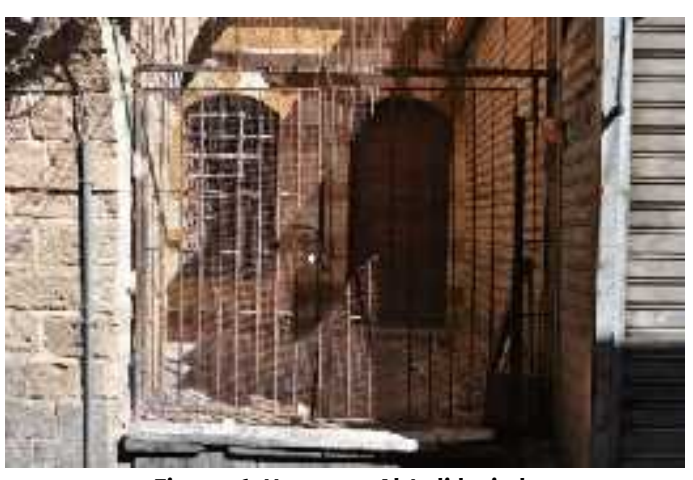

Figure36. Hammam Al-Jadid windows

\section{CURRENT STATE}

Ownership of hammam al-Ward shifted over time. Commissioned by the Hammouds, the hammam's ownership was transferred many times to different people and to awqaf. It is documented that the hammam was finally transferred from the waqf registers to members of the Hinawi and Sanioura families in the twentieth century [12].

Today, hammam al-Ward is private property, coowned by three families: Skaffi, Hinawi and Sanioura. It was rented in 1978 by Zein al-Abidin Koteish for the amount of 2 USD per year. Personal efforts in funding restoration works, running the hammam and maintaining it were undertaken by the Koteish family. However, this monument was deeply affected by political turmoil in Lebanon. It shut down in 1982 as a result of the Israeli invasionof Saida where it wasused to store weapons. The hammam was cleared and rehabilitated by the Hariri Foundationin 1988 and again in 1993. These private restoration and maintenance efforts kept the hammam running uninterrupted for anextended period of time until 2009. Since then, alack of rehabilitation fundshas left al-Ward defunct and decaying due to the effects oftime and humidity. Although its mashlah is in a good state, the inner washing spaces are the most deteriorated, especially the hot room, which requires tiling and an adequate plumbing system. The furnace needs renovationas well to ensure safe functioning. Mustafa Koteish, who inherited the rent of this hammam from his father, still pays a rental amount of 800 USD per year to the owners but lacks the financial means for a restoration plan.

With a footprint of 423 meter-square, hammam al-Ward is currentlyclosed but easily accessible at any time of the day. Its guard, Mohamed Al-Baba,owns a restaurant nearby and would only open the hammam's doorfor visitors, explaining the history of the monument and its significance.

\section{CONCLUSION}

\section{A note on social practices}

Hammams remain an important testimony of heritage through their various components: urban, architectural, social and cultural. Saida was home to five hammams that "surpassed that of Beirut in cleanliness[8].
Their proximity to mosques could be related to the importance that Islam sheds on cleanliness of the body in the form of ablutions (wudu'). Hammam alShaykh stood facing al-Kikhia mosque, al-Ward near al'Omari mosque and al-Suq adjacent to al-Battah mosque. In fact, Thursdays (on the eve of Friday, which is an Islamic holyday) was the busiest day for hammams. Going to the hammam was a lively event in households: the family prepared towels and soaps for men who went in the morning and women who went in the afternoon after finishing their household chores. This time schedule was mainly adopted in hammams of Greater Syria, unlike hammams in Turkey that were doubled to accommodate for men and women simultaneously. "A bath at the hammam is truly exceptional. You come out of it rejuvenated and happy, it is a source of happiness."

In the past, hammams were not simply a leisure activity. They were a necessity for Saida's dwellers since they offered running water that wasn't available in households. Therefore, due to the high demand on hammams and the different services they offered, they were highly profitable economic institutions to invest in [13]. Hammams offered a variety of services of wellbeing: waxing, massaging, and rubbing, all part of the hammam ritual and available to both sexes through specialized personnel. Therefore, despite its role in serving hygienic and ritual purity purposes, the hammam also provided a secular space of leisure.The main hall of each hammam (mashlah) is where socializing, resting and relaxing took place. It also offered a public space of integration for women where they were allowed to freely spend their time especially after giving birth or before getting married [8].

Today, the hammam ritual has mostly disappeared and it's very rare to find functional hammams in Saida or Tripoli. The introduction of showers and running water in private residences and the lack of private and public initiatives to maintain these monuments are among the reasons for its decline. Al-Shaykh remains the only hammam functioning in Saida, frequently maintained by the personal initiative of its owner Khalil Halabi. It mostly caters for users who would like to experience this 'notso-modern spa' or groups of men who get together to celebrate on the eve of a friend's wedding. Groups of women as well as domestic and international tourists also visit Hammam al-Shaykh to get a taste of its receding cultural and social traditions since these sites were urban nodes that witnessed various types of social and economic exchanges in the neighborhood and contributed to its development.

\section{ACKNOWLEDGEMENTS}

This article is a result the Saida USUDS project that uncovered much of Saida's treasures and history. Many thanks go to the Saida Municipality and the Hariri Foundation for their support in gathering information and gaining access to Saida's monuments. Special thanks go to my research assistant, Dina Mneimneh, who was a critical researcher with the literature, interviews and field work and who made a significant contribution to this monograph. 


\section{REFERENCES}

[1] M. Al-Khuri, Saida A'bra Hikab al-Tarikh (Saida over the Periods of History). Beirut, 1966.

[2] Shamir Shimon, "The Azm Walis of Syria, (17241785). The period of Dynastic Succession in the Government of the Wilayas, Damascus, Sidon and Tripoli," Ph.D dissertation, Princeton University, 1961.

[3] K. Barbir, Ottoman Rule in Damascus 1708-1758. Princeton University Press, 1980.

[4] Antoine Abdel Nour, Introduction À l'Histoire Urbaine de la Syrie Ottomane (XVle - XVIIle siècle) (Introduction to the Urban History of Ottoman Syria (17th - 18th century)). Beirut: Librairie Orientale, 1982.

[5] G. M. Sinno, Madinat Saida, 1818-1860: Dirassa fil Umran al-Hadariyy min Khilal Watha'ikiha alShar'iyya (The city of Saida, 1818-1860: a study of urban development through its court registers). Beirut, 1988

[6] A. R. Hijazi, Dalil Ma'alem Saida al-Islamiyya (A guide to Saida's religious landmarks). Saida, 1983.
[7] A. K. Rafeq, "Peter Sluglett and Stefan Weber (eds) Syria and Bilad al-Sham under Ottoman Rule," Brill, 2010.

[8] Talal al-Majzoub, Tarikh Saida al-ljtima'iyy (The social history of Saida). Saida, 1983.

[9] 'Abd al-Ghani Al-Nabulsi, Al-Tuhfa al Nabulsiyya fi al-Rihla al Tarabulsiyya (The Nabulsian Treasure on the Trabulsian Travel). Beirut: Heribert Brusse, 1971.

[10] H. Salam-Liebich, The Architecture of Mamluk City of Tripoli. Massachusetts: The Agha Khan Program for Islamic Architecture, 1983.

[11] raphies L. bains de D. Michel Ecochard and Claude LeCoeur, Monographies Architecturales (The bathhouses of Damascus - Architectural Monographs). Institut Français de Damas, 1942.

[12] H. al-A. Al-Daye, "Sidon: a historical and archaeological study of the Ottoman (16th-18th century) Public monuments," Master Arts thesis, Am. Univ. Beirut, vol. Volume 1-2, 1997.

[13] M. Al-Rawas, "Al-Hayat al-Iktisadiyya fi Saida alUthmaniyya (The economic life in Ottoman Saida)," the Lebanese University, 1997. 